\title{
MINERAL CONTENT OF DIFFERENT BOTTLED WATER AVAILABLE IN BANGLADESH: ASSESSMENT OF THEIR COMPLIANCE WITH CURRENT REGULATIONS
}

\author{
MOHAMMAD ARIFUR RAHMAN*, MD. ABDUS SALAM, ABDUS SALAM, \\ MADHUSUDAN ROY, NARGIS JAHAN ARA AND A. M. SHAFIQUL ALAM \\ Department of Chemistry, Dhaka University, Dhaka-1000, Bangladesh
}

\begin{abstract}
Nine bottled water brands collected from retail shops and food shops beside the University of Dhaka were analyzed for their major and trace element constituents to ascertain their suitability for human consumption. The results obtained were compared with parametric values (PVs) set by European Community Council Directive 98/83/EC and the guideline values (GVs) recommended by WHO. It was found that the majority of the brands tested were low in mineral contents. Moreover, lower values of hardness, TDS and conductivity than the prescribed limits of WHO showed that water was deficient in essential minerals. Minerals like magnesium, potassium, calcium were present in some cases in such a low concentration that water seemed to be as good as distilled water. In case of heavy metals, only lead and cadmium were found to be below the detection limit $(0.001 \mathrm{mg} / \mathrm{L})$ which indicates bottled water brands are better for drinking.
\end{abstract}

Key words: Mineral, Guide line, Bottled water, WHO.

\section{Introduction}

Freshwater is scarce and resources are unevenly distributed over the world, with much of the water located far from human populations. The total amount of usable freshwater supply is around $4 \times 106 \mathrm{~km}^{3}$, which is only $0.2 \%$ of all the water on Earth. It is estimated that three billion people will be in the "water scarcity" category (having $<1000 \mathrm{~m}^{3}$ of renewable water per capita per year) by 2025 (UNEP 2002).

In Bangladesh, groundwater abstracted from drilled wells is the sources utilized by the bottled water industry. Despite the continued expansion of the bottled water industry and positive trend on bottled water consumption in Bangladesh, reports on bottled water analysis and their mineral contents are scattered and not well documented. Mineral water in Western countries is obtained from natural springs and is, generally, named after those springs. Most of the bottled water passed off as mineral water in Bangladesh, however, is filtered, boiled or purified by other means such as chlorination, deionization and reverse osmosis. A better description of bottled drinking water sold in Bangladesh therefore, would be "purified bottled water". Given the extensive consumption of bottled water, the question naturally arises of the long-term impact of water of various chemical compositions on human health.

*Corresponding author: Email: marahman76@yahoo.com 
Elements such as magnesium and calcium have been linked to the reduced frequency of sudden death and Osteoporosis respectively and both may exert protective effects against gastric cancer (Garzon and Eisenberg 1998). WHO advocated the consumption of brands that are high in magnesium and calcium and low in sodium. However, individuals with stones in the upper urinary tract are ill-advised to consume bottled drinking water with high calcium content (Mayne and Edwards 1990). Nitrate is a common contaminant in ground water and has been implicated in gastric cancer mortality and other disorders (Schuber et al. 1999 and Lauwerys 1979). Through conversion to nitrite, nitrate is the causative agent of Methaemoglobinemia in infants. Cadmium may have a half-life in bones of 38 years and has carcinogenic properties (Yang et al. 1998). Lead builds up in the body over many years and can cause damage to the brain, red blood cells and kidneys. Children and pregnant women are open to greatest risks. Amounts of lead that won't hurt adults can slow down normal mental and physical development of growing bodies (Needleman 1993). Lead and cadmium are unusual among drinking water contaminants in that they seldom occur naturally in water supplies (Krishnamurti and Viswanathan 1991). Copper is an essential element in human nutrition but it may reach high levels in tap water through contact with copper fittings. It has been found that shortperiod exposure to copper may lead to stomach and intestinal distress, liver and kidney damage and anemia. Persons with Wilson disease may be more sensitive than others to the effects of copper contamination (WHO 1996). Zinc is also known to be a beneficial element when present in low amounts, but may produce various health hazards ranging from anemia to gastric and kidney disorders at higher levels of occurrence.

The main purpose of this study is to investigate the physical and chemical characteristics of some of the most widely distributed domestic brands of bottled water in Dhaka market. Additionally, this paper aims to assess the compliance of Bangladesh bottled water brands to several standards around the world including European Community Council Directive 98/83/EC (EC 1998) and World Health Organization (WHO) guideline values (WHO 2006).

\section{Materials and Methods}

Sampling: Commercially-available nine brands of domestically-produced bottled water were purchased randomly from nearby shops of Dhaka University area in November 2009. The samples were collected from different nearby retail shops of Dhaka university such as (a) Chankarpool (b) In front of Dhaka Medical College (c) New Market area on the $14^{\text {th }}$ October 2009. As indicated on their labels, all the bottled water had a shelf life of one year and were certified by Bangladesh Standard Testing Institute (BSTI). To keep the brand names anonymous, the waters were given a numerical code from 1 to 9 and this convention was used throughout the study. All bottled water were in polyethylene terephthalate (PET) containers with plastic screw caps. The holding capacities of bottled water containers ranged from 0.5 to $2.0 \mathrm{~L}$. After the collection of samples, they were 
brought to the laboratory, where they were stored in the refrigeration at $4{ }^{\circ} \mathrm{C}$ and in the dark until analysis. Prior to analysis, manufacturer seals were broken in the laboratory and then two $50 \mathrm{~mL}$ aliquots were aseptically removed from each bottle for anion and cation analyses. These samples were placed in sterile high density polyethene (HDPE) containers, which were carefully rinsed several times with the sample water. Water samples were not acidified or filtered, but they were analyzed in the normal condition. Collected bottled water samples did not contain any particulates. Manufacturer labels on the bottles were used as a source of basic information on a particular water sample.

Physical and chemical analysis of samples: Color, taste, $\mathrm{pH}$, specific conductance, total dissolved solids (TDS), total hardness, chlorides, nitrates, sulphates, phosphates, copper, iron, magnesium, calcium, manganese, lead, zinc, cadmium, chromium and nickel were analyzed. All the samples were taken in different $100 \mathrm{~mL}$ transparent beaker, then the colors were observed, $\mathrm{pH}$, and specific conductance were measured and the taste was taken. TDS were calculated by the following formula:

$\%$ of dissolved solids $=\mathrm{K} \times 0.062$, Where $\mathrm{K}$ is the specific conductance.

Methods of Analysis: Total hardness of the samples was determined by complexometrically where $\mathrm{Na}_{2}$ EDTA was used as complexing agent and Erichrome black $\mathrm{T}$ was used as indicator. Chlorides content in a sample was determined by mercuric nitrate method (Vogel 2002), it is a titrimetric method, in which a mixed indicator is used. The nitrate, sulphate and phosphates were determined by using UV spectrophotometer (UV-160A, Shimadju, Japan) at 410, 380 and $358 \mathrm{~nm}$ wavelength respectively (Horwitz 2001). For this technique calibration curve was prepared using standard solutions. Copper, iron, magnesium, calcium, manganese, lead, zinc, cadmium, chromium and nickel were determined by Atomic Absorption Spectrometer (A Analyst 800, Perkin Elmer, USA) (Vogel 2002). Before analysis the samples were concentrated 10 times by evaporation and the reading was taken with AAS.

\section{Results and Discussion}

According to WHO guidelines, the maximum desirable limit of $\mathrm{pH}$ is $7.0-8.5$. EC established $\mathrm{pH}$ limits from $6.5-9.5$. Water with $\mathrm{pH}$ lower than 4.0 have a sour taste and above 8.5 an alkaline bitter taste (EC 1998). High pH induces the formation of trihalomethanes, which are toxic. $\mathrm{pH}$ below 6.5 starts corrosion in pipes, thereby releasing toxic metals such as $\mathrm{Zn}, \mathrm{Pb}, \mathrm{Cd}$ and $\mathrm{Cu}$, etc. Out of total nine samples analyzed, eight had $\mathrm{pH}$ values between 7 and 7.5. One sample was just slightly acidic with $\mathrm{pH}$ values of 6.98 , thus all the commercially available drinking water samples analyzed had $\mathrm{pH}$ within the prescribed limits recommended by WHO/EC. All the samples analyzed had conductance well within the prescribed limit of $2500 \mu \mathrm{S} / \mathrm{cm}$ by EC. The conductance is a reflective of dissolved mineral solids (Trivedi and Goel 1986). The presence of dissolved solids in water does affect its taste. As per the ISI (Indian Standard Specification for 
Drinking Water 1983) rating about palatability of drinking water, in relation to its TDS, water may be considered as TDS $<300 \mathrm{mg} / \mathrm{L}$-excellent; $300-600 \mathrm{mg} / \mathrm{L}$ - good; 600900mg/L-fair; 900-1200mg/L-poor and >1200mg/L-unacceptable. All the samples fall in the category of 'excellent'. This is the general impression of all Bangladeshi people that (genuine) bottled water has a very good taste. But water with extremely low concentration of TDS may also be unacceptable and may be flat and insipid in taste and lacking minerals. It was observed that all the samples had TDS values lower than the prescribed limit of $500 \mathrm{mg} / \mathrm{L}$. Both conductance and TDS point out that demineralization had been carried out to more than the desirable limit. The results are presented in the Tables 1-3. The recommended guideline values for drinking water are presented in Table 4.

Table 1. Analysis results of physical parameters of nine Bangladeshi bottled water.

\begin{tabular}{cc|c|c|r|r}
\hline Code & Name & $\mathbf{p H}$ & $\begin{array}{c}\text { Conductance } \\
(\boldsymbol{\mu S} / \mathbf{c m})\end{array}$ & $\begin{array}{r}\text { TDS } \\
(\mathbf{m g} / \mathbf{L})\end{array}$ & $\begin{array}{c}\text { Total } \\
\text { hardness(mg/L) }\end{array}$ \\
\hline 1 & Mum & $7.19 \pm 0.05$ & $300 \pm 2.0$ & $186 \pm 2.5$ & $30.5 \pm 0.5$ \\
2 & Jibon & $7.31 \pm 0.04$ & $100 \pm 0.8$ & $62 \pm 1.0$ & $125.6 \pm 1.2$ \\
3 & Libra & $7.06 \pm 0.05$ & $200 \pm 1.3$ & $124 \pm 1.5$ & $96.2 \pm 0.8$ \\
4 & Santi & $7.55 \pm 0.06$ & $100 \pm 0.5$ & $62 \pm 1.0$ & $11.5 \pm 0.5$ \\
5 & Pran & $7.24 \pm 0.06$ & $0 \pm 0.05$ & $0 \pm 0.5$ & $102.6 \pm 1.2$ \\
6 & Fresh & $7.73 \pm 0.08$ & $100 \pm 0.6$ & $62 \pm 1.1$ & $160.5 \pm 1.6$ \\
7 & Spa & $6.98 \pm .02$ & $400 \pm 3.2$ & $248 \pm 2.5$ & $120.6 \pm 1.0$ \\
8 & Nayagra & $7.02 \pm .03$ & $200 \pm 1.3$ & $124 \pm 1.2$ & $112.0 \pm 0.9$ \\
9 & Acme & $7.50 \pm .05$ & $100 \pm 0.6$ & $62 \pm 0.5$ & $56.2 \pm 0.3$ \\
\hline
\end{tabular}

The limits of WHO for hardness for drinking water are between $100-500 \mathrm{mg} / \mathrm{L}$. Hardness of water which is due to the presence of calcium and magnesium salts in water, does contribute towards total calcium and magnesium human dietary needs, which has a beneficial effect on bone structure. Studies on water hardness and cardiovascular disease mortality have suggested a lower incidence of heart disease in communities drinking of hard water. Extremely hard water (hardness $4500 \mathrm{mg} / \mathrm{L}$ ) is also unfit for consumption because the constituent minerals such as calcium can deposit inside the body if present in high amounts leading to kidney or gall bladder stones. Consumption of very soft water (less than $50 \mathrm{mg} / \mathrm{L}$ ) lacking in essential minerals like calcium, magnesium and other trace minerals is also harmful for the body because water low in mineral content would rob off the body's minerals. People drinking such treated water excrete huge amounts of calcium, magnesium and other trace minerals in urine (Consumer Research 1991). The more the mineral loss, the greater the risk for osteoporosis, osteoarthritis, hypothyroidism, coronary artery disease, high blood pressure and a long list of degenerative diseases generally associated with premature aging. Also, cooking food in soft water pulls the minerals out of them and lowers their natural value. All the nine 
samples presently analyzed had hardness higher than the lower limit of $100 \mathrm{mg} / \mathrm{L}$. Most of the samples had calcium and magnesium higher than the respective lower limit of 75 and $30 \mathrm{mg} / \mathrm{L}$ as prescribed by the WHO. Even some samples had zero calcium content. Thus $100 \%$ of the samples were of the lower limit of the WHO for calcium and magnesium.

Chloride content of the nine samples was in the range from $4.08-71.57 \mathrm{mg} / \mathrm{L}$ whereas the EC prescribed a limit of $250 \mathrm{mg} / \mathrm{L}$ in drinking water. Thus, all the bottled water samples were safe for drinking with respect to chloride content. Seven out of nine samples analyzed had nitrate content below the WHO recommended limit of $50 \mathrm{mg} / \mathrm{L}$ and hence do not pose health concern. And two out of nine had extremely low values than the WHO limit for nitrate. Nitrate levels above the WHO Maximum Contaminant Level of $45 \mathrm{mg} / \mathrm{L} \mathrm{NO}_{3}{ }^{-}$may cause methemoglobinemia in infants. Sulfate in drinking water currently has a maximum contaminant level (SMCL) of $250 \mathrm{mg} / \mathrm{L}$, based on aesthetic effects (i.e., taste and odor) (Indian Standard Specification for Drinking Water 1983). This regulation is not a federally enforceable standard, but is provided as a guideline for states and public water systems. EPA estimates that about $3 \%$ of the public drinking water systems may have sulfate levels of $250 \mathrm{mg} / \mathrm{L}$ or greater. Two out of nine samples analyzed have sulphate above the prescribed limit. Phosphates obtained in the samples are from 4.33 to $32.85 \mathrm{mg} / \mathrm{L}$. Though there is no standard value of phosphate in drinking water but when the concentration of phosphates rises above $100 \mathrm{mg} / \mathrm{L}$ the coagulation processes in drinking water treatment plants may be adversely affected.

Table 2. Analysis results of major anionic constituents of nine Bangladeshi bottled water.

\begin{tabular}{c|c|c|c|r|r}
\hline Code & Name & $\mathbf{C l}^{-}(\mathbf{m g} / \mathbf{L})$ & $\mathbf{N O}_{\mathbf{3}}{ }^{-}(\mathbf{m g} / \mathbf{L})$ & $\mathbf{S O}_{\mathbf{4}}{ }^{2-}(\mathbf{m g} / \mathbf{L})$ & $\mathbf{P O}_{\mathbf{4}}{ }^{3-} \mathbf{m g} / \mathbf{L}$ \\
\hline 1 & Mum & $34.08 \pm 0.80$ & $72.93 \pm 0.80$ & $17.99 \pm 1.20$ & $9.69 \pm 0.30$ \\
2 & Jibon & $10.22 \pm 0.30$ & $18.03 \pm 0.60$ & $5.56 \pm 0.20$ & $11.33 \pm 0.20$ \\
3 & Libra & $10.22 \pm 0.50$ & $110.66 \pm 0.90$ & $0.14 \pm 0.02$ & $10.32 \pm 0.10$ \\
4 & Santi & $8.860 \pm 0.40$ & $20.74 \pm 0.40$ & $12.97 \pm 0.10$ & $11.74 \pm 0.40$ \\
5 & Pran & $4.089 \pm 0.60$ & $8.322 \pm 0.20$ & $9.45 \pm 0.30$ & $5.87 \pm 0.20$ \\
6 & Fresh & $25.21 \pm 0.50$ & $12.84 \pm 0.40$ & $20.47 \pm 0.20$ & $7.26 \pm 0.20$ \\
7 & Spa & $71.56 \pm 0.60$ & $21.87 \pm 0.30$ & $72.37 \pm 2.10$ & $32.85 \pm 0.50$ \\
8 & Nayagra & $17.04 \pm 0.20$ & $17.50 \pm 0.20$ & $49.57 \pm 0.50$ & $4.33 \pm 0.20$ \\
9 & Acme & $4.08 \pm 0.20$ & $14.34 \pm 0.50$ & $6.28 \pm 0.20$ & $6.04 \pm 0.20$ \\
\hline \multicolumn{7}{r}{$\mathrm{n}=3$ (no. of analysis) } & & & &
\end{tabular}

Copper is an essential element for living organisms, including humans, and-in small amounts-necessary in our diet to ensure good health. However, too much copper can cause adverse health effects, including vomiting, diarrhoea, stomach cramps and nausea. It has also been associated with liver damage and kidney disease. The human body has a natural mechanism for maintaining the proper level of copper in it. However, children under one year old have not yet developed this mechanism and, as a result, are more 


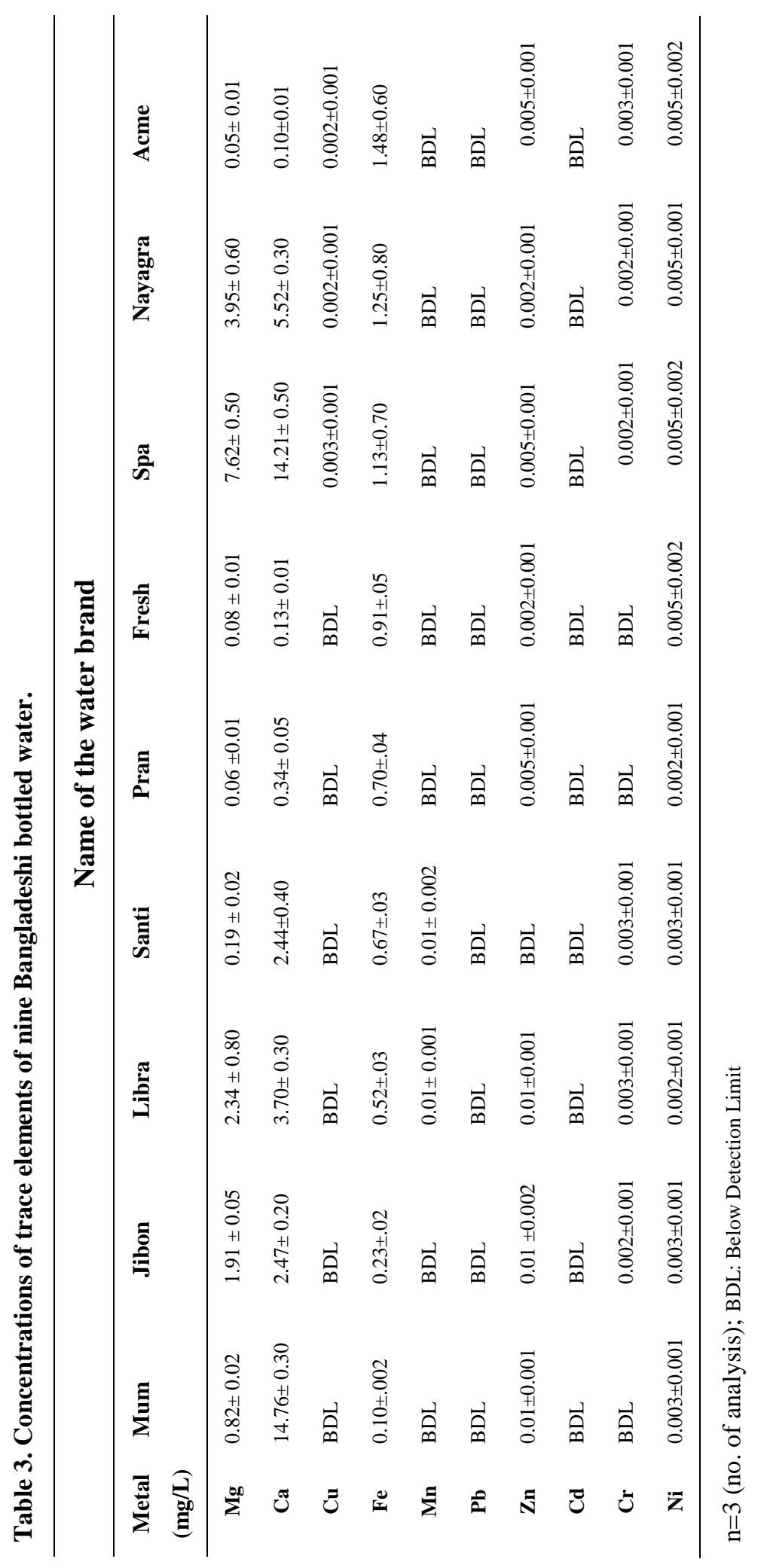


vulnerable to the toxic effects of copper. People with Wilson's disease also have a problem with maintaining the proper balance and should also exercise particular care in limiting exposure to copper. Water brands analyzed contain 0.002 to $0.003 \mathrm{mg} / \mathrm{L}$ and most of the brand has below the detection limit of the instrument $(0.001 \mathrm{mg} / \mathrm{L})$ for Flame Atomic Absorption Spectrophotometer). These results are presented in Table 3. When the level of iron in water exceeds $0.3 \mathrm{mg} / \mathrm{L}$ limit, we experience red, brown, or yellow staining of laundry, glassware, dishes and household fixtures such as bathtubs and sinks. The water may also have a metallic taste and an offensive odor. Water system piping and fixtures can also become restricted or clogged. Water analyzed here contains 0.10 to $1.48 \mathrm{mg} / \mathrm{L}$. EC has a guideline about $2.0 \mathrm{mg} / \mathrm{L}$ iron may contain in drinking water. Here eight out of nine did not follow the guideline value. So the water brands are not good for health with respect to iron except MUM. All the samples analyzed contain manganese which varied from 0.001 to $0.002 \mathrm{mg} / \mathrm{L}$ below the upper limit $0.05 \mathrm{mg} / \mathrm{L}$ prescribed by WHO and EC and few contains below the detection limit of the instrument. All the samples are good for drinking with respect to manganese. All the brands analyzed had lead below the detection limit of the instrument and also below the maximum guideline value of WHO and EC. All the brands are good under the guideline of EC and WHO with respect to lead.

Acute toxicity arises from the ingestion of excessive amounts of zinc salts, either accidentally or deliberately as an emetic or dietary supplement. Vomiting usually occurs after the consumption of more than $500 \mathrm{mg}$ of zinc sulfate. Mass poisoning has been reported following the drinking of acidic beverages kept in galvanized containers; fever, nausea, vomiting and stomach cramps occurred $3-12 \mathrm{~h}$ after ingestion. Food poisoning attributable to the use of galvanized zinc containers in food preparation has also been reported; symptoms occurred within $24 \mathrm{~h}$ and included nausea and vomiting, sometimes accompanied by bleeding and abdominal cramps. Impairment of the copper status of volunteers by dietary intake of $18.5 \mathrm{mg}$ of zinc per day has been reported. Gastric erosion is another reported complication of a daily dosage of $440 \mathrm{mg}$ of zinc sulfate. Daily supplements of $80-150 \mathrm{mg}$ of zinc caused a decline in high-density lipoprotein cholesterol levels in serum after several weeks. The brands analyzed contain 0.002 to $0.01 \mathrm{mg} / \mathrm{L}$ Zinc. The sample contains a little Zinc which is not so bad for health. All the samples analyzed contain cadmium below the detection limit of the instrument that means it is very low in concentration. The guideline value of WHO and EC are 3.0 and $5.0 \mathrm{mg} / \mathrm{L}$ respectively (Table 4). All the samples are good for health with respect to cadmium.

Chromium has the potential to cause the following effects from a lifetime exposure at levels above the MCL: damage to liver, kidney circulatory and nerve tissues; skin irritation. The daily chromium requirement for adults is estimated to be $0.5-2 \mu \mathrm{g}$ of absorbable chromium (III) If a fractional absorption value of $25 \%$ for "biologically incorporated" chromium (III) in food is assumed, this is provided by a daily dietary 
intake of $2-8 \mu \mathrm{g}$ of chromium (III) equivalent to $0.03-0.13 \mu \mathrm{g}$ of chromium (III) per $\mathrm{kg}$ of body weight per day for a 60-kg adult. Ingestion of (1-5)g of "chromate" (not further specified) results in severe acute effects such as gastrointestinal disorders, haemorrhagic diathesis and convulsions. Death may occur following cardiovascular shock. In some

Table 4. Drinking water standards recommended by WHO and EC.

\begin{tabular}{|c|c|c|c|c|c|c|c|c|c|c|}
\hline $\begin{array}{c}\text { Characte } \\
\mathbf{r}\end{array}$ & $\mathbf{p H}$ & \multicolumn{2}{|c|}{$\begin{array}{c}\text { Conductanc } \\
\text { e }(\mu \mathrm{S} / \mathrm{cm})\end{array}$} & TDS & $\begin{array}{c}\text { Total } \\
\text { hardness } \\
(\mathrm{mg} / \mathrm{L})\end{array}$ & \multicolumn{2}{|c|}{$\begin{array}{c}\mathbf{C l}^{-} \\
(\mathrm{mg} / \mathrm{L})\end{array}$} & $\begin{array}{c}\mathbf{S O}_{4}^{2-} \\
(\mathrm{mg} / \mathrm{L})\end{array}$ & $\begin{array}{c}\mathbf{N O}_{3}^{-} \\
(\mathrm{mg} / \mathrm{L})\end{array}$ & $\begin{array}{l}\mathbf{P O}_{4}{ }^{3-} \\
(\mathrm{mg} / \mathrm{L})\end{array}$ \\
\hline $\begin{array}{l}\text { WHO } \\
\text { limit }\end{array}$ & $7-9.2$ & . & & $\begin{array}{l}500- \\
1500\end{array}$ & 300 & 20 & -600 & 200 & 50 & - \\
\hline EC limit & $6.5-9.5$ & 25 & & $0-500$ & - & & 50 & - & 50 & - \\
\hline Character & $\begin{array}{c}\mathbf{C a} \\
\mathrm{mg} / \mathrm{L}\end{array}$ & $\begin{array}{c}\mathbf{M g} \\
\mathrm{mg} / \mathrm{L}\end{array}$ & $\begin{array}{c}\text { Mn } \\
\mathrm{mg} / \mathrm{L}\end{array}$ & $\begin{array}{c}\mathbf{F e} \\
\mathrm{mg} / \mathrm{L}\end{array}$ & $\begin{array}{c}\mathbf{P b} \\
\mathrm{mg} / \mathrm{L}\end{array}$ & $\begin{array}{c}\mathrm{Cu} \\
\mathrm{mg} / \mathrm{L}\end{array}$ & $\begin{array}{c}\mathbf{Z n} \\
\mathrm{mg} / \mathrm{L}\end{array}$ & $\begin{array}{c}\mathbf{C d} \\
\mathrm{mg} / \mathrm{L}\end{array}$ & $\begin{array}{c}\mathbf{C r} \\
\mathrm{mg} / \mathrm{L}\end{array}$ & $\begin{array}{c}\mathbf{N i} \\
\mathrm{mg} / \mathrm{L}\end{array}$ \\
\hline WHO limit & $75-200$ & $30-150$ & 0.4 & - & 0.01 & 2.0 & 3.0 & 0.003 & 0.05 & 0.02 \\
\hline EC limit & $0-200$ & - & 0.5 & 2.0 & 0.01 & 2.0 & $0.0-5.0$ & $\begin{array}{ll}0 & 0.005\end{array}$ & 0.05 & 0.02 \\
\hline
\end{tabular}

occupational studies, increased incidences of genotoxic effects such as chromosomal aberrations and sister chromatid exchanges have been found in workers exposed to chromium (VI) compounds (Garzon and Eisenberg 1998). In epidemiological studies, an association has been found between occupational exposure to chromium (VI) compounds and mortality due to lung cancer. All the brands analyzed here contain BDL (Below detection level) to $0.003 \mathrm{mg} / \mathrm{L}$ chromium which is below the guideline value of WHO and EC. Therefore, the brands are free from toxic effects of chromium in drinking. Nickel is an important metal that occurs widely in the environment and is found naturally in odd and drinking water. It is known to be toxic at high intakes but toxicity in humans, other than those exposed in particular industrial circumstances, is very unusual. The World Health Organization considered nickel in their drinking water guidelines and developed a guideline value of $0.02 \mathrm{mg} / \mathrm{L}$ based on effects in laboratory animals. The EC has established a lifetime drinking water health advisory level of $0.02 \mathrm{mg} / \mathrm{L}$ based on the same studies as those used to develop WHO guidelines. The brands analyzed contain nickel below the WHO and EC limit. Under the guideline of both WHO and EC all the brands are safe for drinking. The analytical quality control included daily analysis of standards and triplicate analysis of samples and blanks. The accuracy and precision of the analytical technique was evaluated by analyzing a certified standard reference material, CWW-TM-B, Certified Waste Water Trace Metals Solution (B) (High-Purity Standards, Charleston, SC, USA). The relative error (RE, \%) is less than $\pm 5 \%$ for all analyzed elements. 


\section{References}

Consumer Research, 1991. How good is bottled water? Consumer Res. 3, $10-15$.

EC, 1998. Council Directive 98/83/EC of 3 November 1998 on the quality of water intended for human consumption. Official Journal of the European Communities L, 330, 32-54.

Garzon, P. and M. J. Eisenberg, 1998. Variations in the mineral content of commercially available bottled waters: Implications for health and disease. American J. Med., 105, 125 - 130.

Indian Standard Specification for Drinking Water. 1983. IST, IS 10500.

Krishnamurti, C. R and V. Pushpa. 1991, Toxic metals in the Indian environment. New Delhi: Tata McGraw- Hill Limited. pp 161 - 164.

Lauwerys, R. R. 1979. Health effects of cadmium. In: Di Ferrante E, (ed.) Trace metal exposure and health effects. Oxford: Pergamon Press. pp $43-64$.

Mayne, P. D. and L. Edwards, 1990. What on earth are we drinking? Brazilian J. Urol., 66, 123 126.

Needleman H.L. 1993, The current status of childhood low-level lead toxicity. Neurotoxicity 14, $161-166$.

Schuber, C, L. Knobelcoh, M. S. Kanarek and H. A. Anderson, 1999. Public response to elevated nitrate in drinking water wells in Wisconsin. Arch Environ Health, 54, 242 - 247.

Horwitz, W, 2001. Official Methods of Analysis of AOAC international, $17^{\text {th }}$ edition, Volume II, USA. pp 5-45.

Trivedi, R. K and P. K. Goel. 1986. Chemical and Biological Methods for Water Pollution Studies. Karad: Environmental Publications. pp.173-184.

UNEP, 2002. Global environment outlook 3 - Past, present and future perspectives. Earthscan Publications Ltd., London. pp. 125 - 149.

Vogel, A. I. 2002. Vogel's Quantitative Chemical Analysis, 6th edition, L.P.E. pp. 408, 470, 473,522,658, 676, 541 and 603-610.

WHO, 1996. Guidelines for drinking water quality, health criteria, and other supporting information. 2nd ed. Geneva: WHO. pp. $367-370$.

WHO, 2006. Guidelines for drinking-water quality, first addendum to third edition, Volume 1, Recommendations, Geneva. pp. 55-70.

Yang, C. V., M. F. Chang, S. S. Tsai and Y. L. Hseih, 1998, Calcium, magnesium, and nitrate in drinking water and gastric cancer mortality. Jpn J. Cancer Res. 89:124 - 130. 